\title{
INJECTABLE COLLAGEN IN CORRECTION OF AGE-RELATED SKIN CHANGES: EXPERIMENTAL AND CLINICAL PARALLELS
}

Manturova $N E^{1}$, Stenko $A G^{2}$, Petinati $Y A^{3}$, Chaikovskaya $E A^{2} \bowtie$, Bolgarina $A A^{4}$

${ }_{1}^{1}$ Pirogov Russian National Research Medical University, Moscow, Russia

${ }^{2}$ Institute of plastic surgery and cosmetology, Moscow, Russia

${ }^{3}$ Izmerov Research Institute of Occupational Health, Moscow, Russia

${ }^{4}$ LLC Nearmedic PLUS, Moscow, Russia

To a large extent, age-related facial skin changes, wrinkles and flabbiness, are attributed to the structural alterations in dermis, including of collagen fibers fragmentation and disorganization. There are various cosmetological correction methods that aim to activate neocollagenesis and dermal remodeling. From this perspective, intradermal injections of exogenous collagen preparations seem logical. This study aimed to investigate the efficacy and safety of Collost $7 \%$ collagen complex applied to correct the age-related facial skin changes, as well as clarify the possible mechanisms of skin rejuvenation resulting from a course of intradermal injections. 35 participants entered the study, 30 of them finished it. A set of indicators describing age-related skin changes was assessed with the help of clinical scales; the assessment revealed a pronounced improvement in the quality of the patients' skin, including smoothed relief in the area of localization of fine wrinkles. The therapy resulted in a statistically significant improvement of the skin's elasticity, which, combined with the changes discovered through US scanning (greater dermis thickness and echodensity), is an indirect indication of skin restructuring associated with accumulation of fibrous protein structures. These results allow parallels with the experimental data that shows activation of neocollagenesis in the skin of laboratory animals after a course of Collost $7 \%$ gel. The research revealed no serious adverse events. A course of collagen administered intradermally can be recommended as an aesthetic correction procedure, as well as means of prevention of atrophy that has a significant effect on skin's appearance and health status.

Keywords: skin ageing, skin rejuvenation, collagen injection

Acknowledgements: the authors would like to thank "Nearmedic Plus" (Moscow) for the support of the clinical observational study, as well as Natalya Indilova, Galina Sofinskaya, Evgenia Ikonnikova, medical researchers of the Institute of Plastic Surgery and Cosmetology, and Olga Bondareva and Olesya Sidorova, doctors with Cosmoprodtest SPC, for the assistance they provided in the context of this study.

Author contribution: Manturova NE — research planning and data interpretation; Stenko AG, Petinati YaA — selection of participants, conducting research, data interpretation; Chaikovskaya EA — research planning, data collection and interpretation, manuscript preparation; Bolgarina AA — literature analysis, research planning.

Compliance with ethical standards: the study was approved by the Society of Aesthetic Medicine ethical committee (Protocol №2 of September 07, 2017). Registration number at www.ClinicalTrials.gov: NCT03677258.

$\triangle$ Correspondence should be addressed: Ekaterina A. Chaikovskaya Olkhovskaya, 27, Moscow, 105066; ktchaikovskaya@yandex.ru

Received: 27.09.2018 Accepted: 25.02.2019 Published online: 09.03.2019

DOI: $10.24075 /$ brsmu.2019.010

\section{ИНЪЕКЦИОННЫЙ КОЛЛАГЕН В КОРРЕКЦИИ ВОЗРАСТНЫХ ИЗМЕНЕНИЙ КОЖИ: ЭКСПЕРИМЕНТАЛЬНО-КЛИНИЧЕСКИЕ ПАРАЛЛЕЛИ}

\section{Н. Е. Мантурова, А. Г. Стенько², Я. А. Петинати, Е. А. Чайковская² $₫$, А. А. Болгарина ${ }^{4}$}

${ }^{1}$ Российский национальный исследовательский медицинский университет имени Н. И. Пирогова, Москва, Россия

${ }^{2} \mathrm{AO}$ «Институт пластической хирургии и косметологии», Москва, Россия

${ }^{3}$ Научно-исследовательский институт медицины труда имени академика Н. Ф. Измерова, Москва, Россия

${ }^{4} \mathrm{OОO} \mathrm{«Ниармедик} \mathrm{Плюс»,} \mathrm{Москва,} \mathrm{Россия}$

Возрастные изменения лица в виде морщин, дряблости кожи во многом связаны со структурными изменениями дермы, в том числе с фрагментацией и дезорганизацией коллагеновых волокон. Различные методы косметологической коррекции направлены на активизацию неоколлагенеза и ремоделирование дермы. С этой точки зрения логичным видится проведение внутрикожных инъекций препаратов экзогенного коллагена. Целью исследования было изучить эффективность и безопасность применения коллагенового комплекса Коллост 7\% в коррекции возрастных изменений кожи лица, а также уточнить возможные механизмы развития эффекта омоложения кожи после курса внутрикожных инъекций. В исследование были включены 34 участницы, завершили его 30 участниц. Оценка комплекса показателей возрастных изменений кожи с помощью клинических шкал продемонстрировала выраженное улучшение качества кожи и разглаживание ее рельефа, особенно в области локализации тонких морщин. После завершения курса лечения достоверно повысилась эластичность кожи лица, что вкупе с изменениями, выявленными при УЗ-сканировании (повышение толщины дермы и ее акустической плотности), косвенно свидетельствует о структурной перестройке кожи с накоплением белковых волокнистых структур. Полученные результаты позволяют проводить параллели с данными экспериментальных исследований, показывающими активизацию неоколлагенеза в коже лабораторных животных после курсового введения геля Коллост 7\%. Серьезных нежелательных явлений при проведении исследования не выявлено. Курсовое внутрикожное введение коллагена можно рекомендовать как процедуру эстетической коррекции, а также в качестве профилактики развития атрофических процессов, которые существенно сказываются на внешнем виде и здоровье кожи.

Ключевые слова: старение кожи, омоложение кожи, инъекции коллагена

Благодарности: авторы благодарят компанию ООО «Ниармедик Плюс» (Москва) за поддержку клинического наблюдательного исследования, а также благодарят Наталью Индилову, Галину Софинскую, Евгению Иконникову — врачей-исследователей АО «Институт пластической хирургии и косметологии»: Ольгу Бондареву, Олесю Сидорову — врачей НПЦ «Космопродтест» за помощь в проведении исследования.

Информация о вкладе авторов: Н. Е. Мантурова - планирование исследования и интерпретация данных; А. Г. Стенько, Я. А. Петинати - подбор участников, проведение исследования, интерпретация данных; Е. А. Чайковская - планирование исследования, сбор и интерпретация данных, подготовка рукописи; А. А. Болгарина - анализ литературы, планирование исследования.

Соблюдение этических стандартов: исследование одобрено этическим комитетом Общества эстетической медицины (протокол № 2 от 7 сентября 2017 г.). Регистрационный номер на портале www.ClinicalTrials.gov — NCT03677258.

$\triangle$ Для корреспонденции: Екатерина Александровна Чайковская

ул. Ольховская, д. 27, г. Москва, 105066; ktchaikovskaya@yandex.ru

Статья получена: 27.09.2018 Статья принята к печати: 25.02.2019 Опубликована онлайн: 09.03.2019

DOI: $10.24075 /$ vrgmu.2019.010 
In the body, skin is multifunctional: it is a barrier and thermal regulator, immune defense forefront and producer of a wide range of hormones. Lately, its social function has been drawing much attention, since appearance of the face, its aesthetic qualities and signs of diseases thereon, largely define the person's "external" age. Youthfulness and attractiveness of the face help people communicate, socialize and maintain the desired level of social life, which, one way or another, affects their quality of life and determines personal and professional success [1]. Therefore, medical researchers continue to study all the aspects of correction of age-related facial skin changes, with a certain number of such efforts addressing the topics of efficacy and safety of the products and methods developed.

Assessing external age, people primarily focus on how noticeable facial wrinkles and skin folds are [2, 3]. The wrinkles and folds depend on biomechanical properties of skin $[4,5]$, which, in turn, are a reflection of the state of dermis' extracellular matrix, or connective tissue layer.

Collagen is the basic protein of any connective tissue, and half of its total amount resides in surface tissues, making up about $70 \%$ of the skin proteins [6]. The main structural components of the dermis are fiber-forming collagens of types I and III. Their complex architectonics define skin's sturdiness, elasticity, ability to repair $[1,5,7,8]$. With age, collagen matrix changes significantly. In part, the change is the results of the predetermined normal ageing processes, but there are other factors that speed up these processes, including diseases, endocrine profile alterations, smoking, unhealthy nutritional habits, UV radiation, pollutants found in the environment [1, 9-12]. The studies conducted to date show that the content of collagen in dermis decreases progressively as people age. After 40 , a woman loses approximately $20 \%$ of her skin's collagen every 10 years [7]. Different research contain different specific data [13-16], but the trend is the same: as people age, proliferative and synthesizing functions of fibroblasts fade, their pool diminishes, cells convert to an inactive "collapsed" phenotype [17]. The quality of collagen fibers changes together with the quantity: they become compacted due to the development of additional covalent cross-links of polypeptide chains. Such structures are more resistant to the action of matrix metalloproteinases, which catabolize proteins and thus incite their renewal. Randomly positioned fragmented collagen fibers that lose focal contacts with fibroblasts accumulate in extracellular matrix. Cells lose structural and functional contact with the matrix and convert to an inactive phenotype [9, 12, 17-19]. Thus forms the vicious circle: the changes of the skin's structure that draw the clinical picture of an "aged face" consolidate. This thesis is confirmed by the fact that in systemic scleroderma patients, whose skin is thicker and contains a greater amount of collagen, age-related facial changes wrinkles, folds and enlarged pores - manifest themselves much later [20].

The above justifies the need for further examination of various cosmetic methods to restore the collagen framework of dermis. Along with the aesthetic aspect, it is very important to work on restoring the skin's reparative resource: as an organized fiber network, collagen participates in regulation of migration, proliferation, differentiation of cells and their interaction [8, 21].

Topical retinoid preparations, laser irradiation and intradermal injection of fillers (gels of stabilized hyaluronic acid, polylactic acid, calcium hydroxyapatite particles) were proven to reliably induce neocollagenesis [22-26]. The action mechanisms of these means differ, but the result of their application is the same: affected skin develops a dense fibrous collagen network. The same purpose drives research of such methods as intracutaneous injection of active peptides, microgranules of polycaprolactone, implantation of polycaprolactone threads, exposure to radio frequencies and microfocused ultrasound, mechanical microperforation of skin, etc. Injecting the dermis proper with collagen appears etiologically sound. Aesthetic collagen therapy has been officially recognized about 40 years ago: in 1981, FDA (Food and Drug Administration) registered the first injection material based on this substance. Medical products developed around cow skin collagen are safe and show good biocompatibility [27]. The assumed pattern of action of collagen materials administered intradermally includes temporary hydration of dermis, optimization of the extracellular matrix properties, and stimulating effect of short peptides (matricins), a product of biodegradation of exogenous collagen $[8,28,29]$. Via the biological feedback mechanism, protein fragments accumulation per se stimulates synthesis of protein de novo [30].

Collost $7 \%$ and Collost $15 \%$ collagen material in the form of sterile gel products were developed and are produced in Russia by BioPHARMAHOLDING; the gels find use in various situations related to medical treatment, including cosmetological procedures. The collagen for Collost is derived from cattle hides; it is purified to remove the impurities without breaking the native fibrous structure and corrupting properties of the protein. The material is registered as an injectable medical product (FSR 2008/02112 of February 26, 2016). In cosmetology, Collost gels are prescribed to counter skin ageing and atrophy. Intradermal injections of the material instantly eliminate the soft tissue volume deficiency; administered as a course, it guarantees lasting results [31, 32]. A test for hypersensitivity to animal collagen is a mandatory measure before any procedures involving Collost gels.

Metabolism and biochemical effects of a Collost $7 \%$ gel implanted into the skin were detailed in the context of recent experimental studies [21]. Laboratory animals (rats) were injected with the material intradermally twice. Throughout the entire observation period, which lasted 37 weeks, the researchers noted constant growth of the levels of total collagen and its soluble fraction. According to the researchers, within the several few days after the injection ( $2^{\text {nd }}$ and $7^{\text {th }}$ days) collagen level grows due to the presence of exogenous protein, whereas after a considerable period of time $\left(21^{\text {st }}\right.$ and $37^{\text {th }}$ days) the same trend signals of activation of neocollagenesis in the skin. This hypothesis is also confirmed by the fact that within the same timespans there was registered a significant intensification of incorporation of radiomarked C14 amino acids into the skin protein. Through the seven days of observation, collagenalytic tissue activity was accelerating, which may be the result of the foreign protein biodegradation. The discovered processes suggest that exogenous collagen that has its native structure preserved stimulates synthesis of the skin's native protein while biodegrading.

One of the objectives of the prospective observational study "Investigation of efficacy and safety of Collost $7 \%$ collagen recovery complex applied to correct age-related skin changes" was to clarify, applying non-invasive diagnostic methods, the possible mechanisms of skin rejuvenation during and after a course of intradermal injections.

\section{PATIENTS AND METHODS}

The study lasted from October 2017 to June 2018; it was conducted at the Institute of Plastic Surgery and Cosmetology and Izmerov Research Institute of Occupational Health. Thirty- 
four participants were screened for fitness to accept a course of Collost injections, 30 were found fit.

Inclusion criteria: female; age 35-65 years; skin phototypes I-III; signs of facial skin age-related changes; no chronic diseases at the stage of decompensation; abstention from any cosmetic procedures during the study. Exclusion criteria: pregnancy; lactation; infection; dermatosis; malignant skin neoplasms in the supposed correction zone; systemic connective tissue diseases that damage skin and subcutaneous tissue (systemic lupus erythematosus, ring granuloma, discoid lupus erythematosus, scleroderma, dermatomyositis, etc.); exacerbation or decompensation of chronic somatic diseases; infectious, oncological diseases; coagulation disorders, including iatrogenic caused by drugs taken; use of isotretinoin within the previous 6 months; propensity hypertrophic and keloid scars; use of antihistamines, glucocorticoids, NSAIDs, immunosuppressants and other drugs that affect skin reactivity; hypersensitivity to the components of the studied medical product.

The participants were 36 to 64 years old, (average age 48.50; $25^{\text {th }}$ and $75^{\text {th }}$ percentiles -43.00 and 57.00 years), Caucasian, with a body weight of $52-80 \mathrm{~kg}$ and body mass index less than 30. To avoid skewing the clinical picture of facial skin ageing, the participants maintained a stable body weight (fluctuations of $2 \mathrm{~kg}$ max.) through the entire observation period. No allergies were found in the histories of $93.33 \%$ of participants; all of them had no allergic reaction to local anesthetics. The majority of patients (24 people, $80.00 \%$ ) were non-smoking, all adhered to a mixed diet. The skin of $16.67 \%$ of them was highly sensitive; the thickness and sensitivity of skin of other participants was normal. The "average" participant of this study could be described as follows: a woman about 50 years old with fair skin, photoaging picture fitting her age, with signs of age-related deformational changes on her face that are largely the result of progressing flabbiness, i. e., changes in the skin's biomechanical properties.

Following a detailed examination, the research program included a description of the overall condition of facial skin using 8 indicators (scored against the 5-point Gejnic, Alexiades-Armenakas scale [33, 34]) calculated into an integral skin condition indicator, as well as assessment of wrinkles in 7 zones applying the 5-point MAS (Merz Aesthetic Scale) validated grading scale [35].

The equipment-aided tests were:

- skin elasticity test (cutometry) on forehead, paraorbital zone, cheek, the devices enabling the test were Multi Skin Test Center MC-900 and Cutometer Dual MPA-580 (Courage + Khazaka electronic $\mathrm{GmbH}$; Germany);

- epidermis and dermis thickness test, dermis acoustic density test, implying ultrasound scanning of the equivalent collateral patches of skin using DUB SkinScanner (Taberna pro medicum; Germany) and DermaScan C-System (Cortex Technology; Denmark) featuring 20-22 MHz sensors.

Both medical researchers and participants of the study assessed the efficacy of cosmetological correction course. The latter applied the universal Global Aesthetic Improvement Scale (GAIS) [35].
The results were documented using the LifeViz system (QuantifiCare; France) that makes and enables analysis of 3D images of the face.

To assess the safety of Collost intradermal injections, each procedure was followed by registration of adverse events, immediate and delayed, that could be connected to the individual response to collagen material and/or injection itself.

The study design implied five visits, screening based on inclusion and exclusion criteria, allergy testing as prescribed by the Collost gel material leaflet. Allergy history of the participants and the result of their allergy tests were scrutinized by an immunologist.

The participants received intradermal injections of Collost $7 \%$ three times with an interval of 3 weeks between each. To make the procedures comfortable, they had Acriol Pro anesthetic cream applied to their skin 1 hour prior to injection. The injected amount was $2 \mathrm{ml}$ stored in prefilled syringes that were preheated in a thermostat at $40{ }^{\circ} \mathrm{C}$. The skin was cleaned and disinfected with the help of $0.05 \%$ chlorhexidine digluconate solution; Traumeel gel was applied to the patients' facial skin at the end of each procedure. The participants underwent full examination before the course, prior to each procedure (evaluating the results of the previous ones) and 3 weeks after the course was over.

Statistica 6.0 (Statsoft; Russia) software was used to perform statistical analysis; we used nonparametric methods. The data are presented as medians (Me), $25^{\text {th }}$ and $75^{\text {th }}$ percentiles. The two groups of dependent markers were compared through the Wilcoxon test; the differences were considered statistically significant at $p<0.05$.

\section{RESULTS}

\section{Safety profile analysis}

During the study, all participants exhibited the expected local reactions in the form of skin reddening, slight edemas, palpable pimples at the injection sites. The reactions occurred after the procedures and lasted several hours to several days. In spite of the injection being considerably traumatic, in most cases bleeding took form of petechiae (point hemorrhages), which may be explained by the hemostatic properties of collagen.

\section{Efficacy analysis}

Statistical analysis showed a significant improvement of the clinical and aesthetic properties of facial skin and face on the whole. The integral indicator used to assess the changes decreased significantly $(p<0.05$; screening data compared to data collected after the third procedure) (Table 1): the reduction median was $24.26 \%$. It should be explained here that the integral indicator grows together with the level of contribution of specific markers (wrinkles, folds, rough skin pattern, telangiectasia, etc.) to the "aged face" picture. Thus, when this indicator goes down, the face rejuvenates.

We have registered significant positive trend in the wrinkle depth change $(p<0.05$; screening data compared to data

Table 1. Skin quality indicators, screening and post-course $(p<0.05)$

\begin{tabular}{|l|c|c|}
\hline \multicolumn{1}{|c|}{ Indicator } & Screening & Post-course \\
\hline Integral skin condition indicator, points & $14(10 ; 17)^{\star}$ & $11.5(8 ; 13)$ \\
\hline Wrinkle visibility (consolidated indicator, 7 zones), points & $12(11 ; 16)$ & $8(7 ; 11)$ \\
\hline
\end{tabular}

Note: * - this Table and Table 2 provide median values, brackets contain values of $25^{\text {th }}$ and $75^{\text {th }}$ percentiles. 
collected after the third procedure) (Table 1): the reduction median reflecting the overall visibility of wrinkles on the MAS scale was $28.57 \%$. The detailed analysis of wrinkles in certain zones showed that the most visible changes (skin relief smoothening) occurred on the forehead, paraorbital areas ("crow's feet" wrinkles), lower eyelid and upper lip (Fig. 1).

Skin elasticity in $77 \%$ of participants has improved significantly (Table 2): the indicator growth median was 30.90\% for forehead, $19.10 \%$ for paraorbital area and $15.75 \%$ for cheeks. All changes are significant $(p<0.05$; screening data compared to data collected after the third procedure).

According to the results of the sonography, the following indicators have improved significantly in all participants postcourse: there was an increase in epidermis thickness (by 30.7$39.3 \%$ ), dermis thickness (by 18.7-22.3\%), dermis acoustic density (by $28.7-44.5 \%$, all or some zones of the face) (Table 2, Fig. 2 and 3) ( $p<0.05$; screening data compared to data collected after the third procedure).

All (100\%) participants considered the COllost $7 \%$ gel injection course to be effective. Applying the GAIS scale, half of them called the result satisfactory and expressed a wish to have it improved, while another half was fully satisfied with the result (Fig. 4). From a medical doctor's point of view, a third of participants had the result at the optimal level for them, whereas the majority did not enjoy a full correction but only a considerable improvement. In 2 participants, the improvement was insignificant, an opinion shared by the participants themselves and the medical researcher.

\section{DISCUSSION}

This clinical study confirmed the efficacy of Collost $7 \%$ as a correction product for involutional skin changes. The study employed non-invasive diagnostic methods exclusively, which enabled thorough examination of all participants.

The criteria suggested by Gejnic et al, Alexiades-Armenakas $[33,34]$ were used to assess the overall condition of skin, including photodamage / photoaging symptoms (modified assessment pattern). The integrated indicator combined scores reflecting the state of micro- and macro-relief of the skin, its color, texture, pigmentation, vascular pattern, elastosis and keratosis. Post-course, the indicator has decreased significantly; detailing the results, the visible changes at the skin relief and color levels (wrinkle and folds reduction) should be noted. Two patients with thin skin around eyelids saw the blues spots under their eyes disappear, which was perceived extremely positively by the patients themselves and their close ones. Overall, the skin of most participants, acquired a pink hue and a healthier look.

In the forehead, paraorbital and upper lip zones wrinkles smoothed out the best. These zones have superficial wrinkles associated with the dermal skin layer atrophy/alterations [36]. Restoration of the collagen framework of dermis enables effective correction of skin relief in these areas. However, correcting deep folds (e. g., nasolabial furrows) requires intervention at the level of subcutaneous fat.

Most researchers see a connection between biomechanical properties of the skin and quality of the dermis' fibrous collagen framework. It is logical to assume that the significant skin elasticity improvement registered in the participants may be the result of neocollagenesis, generation of mature fibers with intact structure and sufficient hydrophilicity. The other indirect confirmations of the skin's restructurisation are the increased thickness of dermis and growth of its acoustic density, which were detected by ultrasound scanning. According to the earlier research $[37,38]$, reduction of dermis thickness and acoustic

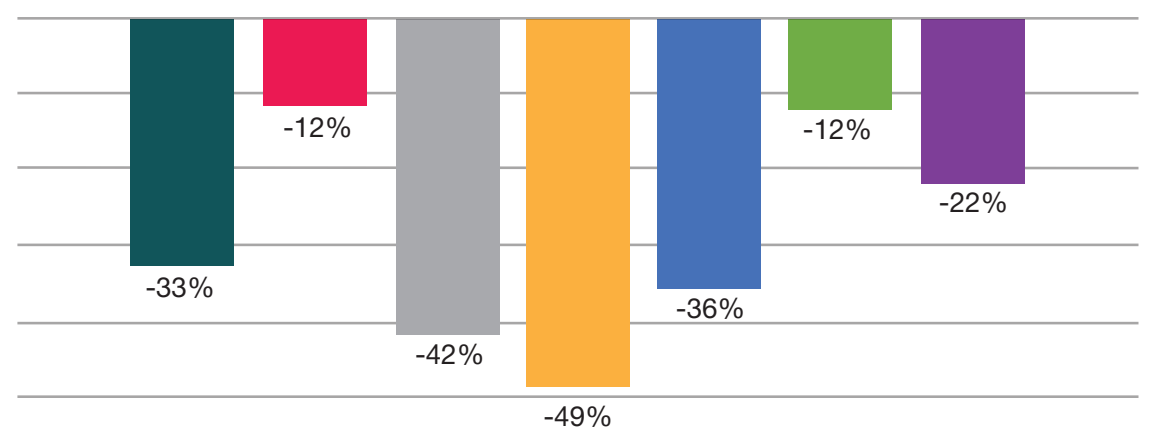

\begin{tabular}{lll}
\hline Forehead & Intercilium & Paraorbital areas \\
Lower eyelid & Upper lip & Nasolabial furrows \\
Labiomental folds & &
\end{tabular}

Fig. 1. Wrinkle visibility change dynamics by face zones (screening data compared to post-course data)

Table 2. Structural and functional skin indicators, screening and post-course $(p<0.05)$

\begin{tabular}{|c|c|c|c|c|c|c|}
\hline \multirow{3}{*}{ Indicators } & \multicolumn{3}{|c|}{ Screening } & \multicolumn{3}{|c|}{ Post-course } \\
\hline & \multicolumn{3}{|c|}{ Zones } & \multicolumn{3}{|c|}{ Zones } \\
\hline & Forehead & Paraorbital area & Cheek & Forehead & Paraorbital area & Cheek \\
\hline $\begin{array}{l}\text { Epidermis thickness } \\
\text { (US scan), mm }\end{array}$ & $\begin{array}{c}0.128 \\
(0.105 ; 0.158)\end{array}$ & $\begin{array}{c}0.110 \\
(0.105 ; 0.133)\end{array}$ & $\begin{array}{c}0.132 \\
(0.108 ; 0.158)\end{array}$ & $\begin{array}{c}0.177 \\
(0.151 ; 0.192)\end{array}$ & $\begin{array}{c}0.163 \\
(0.150 ; 0.184)\end{array}$ & $\begin{array}{c}0.186 \\
(0.162 ; 0.199)\end{array}$ \\
\hline $\begin{array}{l}\text { Dermis thickness } \\
\text { (US scan), mm }\end{array}$ & $\begin{array}{c}1.330 \\
(1.195 ; 1.531)\end{array}$ & $\begin{array}{c}1.206 \\
(1.086 ; 1.376)\end{array}$ & $\begin{array}{c}1.592 \\
(1.256 ; 1.869)\end{array}$ & $\begin{array}{c}1.628 \\
(1.411 ; 1.790)\end{array}$ & $\begin{array}{c}1.496 \\
(1.344 ; 1.672)\end{array}$ & $\begin{array}{c}1.855 \\
(1.685 ; 2.094)\end{array}$ \\
\hline $\begin{array}{l}\text { Dermis acoustic density } \\
\text { (US scan), c. u. }\end{array}$ & $\begin{array}{c}5.102 \\
(3.741 ; 13.190)\end{array}$ & $\begin{array}{c}5.738 \\
(3.778 ; 13.470)\end{array}$ & $\begin{array}{c}5.794 \\
(2.877 ; 11.906)\end{array}$ & $\begin{array}{c}7.236 \\
(5.672 ; 13.540)\end{array}$ & $\begin{array}{c}9.071 \\
(6.026 ; 17.010)\end{array}$ & $\begin{array}{c}6.611 \\
(4.739 ; 13.230)\end{array}$ \\
\hline $\begin{array}{l}\text { Skin elasticity } \\
\text { (cutometry), c. u. }\end{array}$ & $\begin{array}{c}52.63 \\
(46.00 ; 61.45)\end{array}$ & $\begin{array}{c}55.08 \\
(49.85 ; 62.65)\end{array}$ & $\begin{array}{c}55.06 \\
(49.30 ; 62.00)\end{array}$ & $\begin{array}{c}66.75 \\
(56.03 ; 93.39)\end{array}$ & $\begin{array}{c}65.65 \\
(58.00 ; 74.16)\end{array}$ & $\begin{array}{c}63.25 \\
(55.50 ; 61.50)\end{array}$ \\
\hline
\end{tabular}


density is an age-related phenomenon, associated with diseases or steroid-induced atrophy that can be caused by the decreasing content of structural fibrillar proteins. Thus, the growing thickness and acoustic density reflect accumulation of fibrous structures, restructuring of the skin [39, 40]. According to our research, the manifestation of these changes was most evident 3 weeks post-course, which allows a parallel with the afore-mentioned experimental studies that registered the peak of collagen content in the laboratory animals' skin 2-4 weeks after the final Collost $7 \%$ injection.

It should be noted that improvement of the skin's biomechanical properties, the structural changes observed after a course Collost $7 \%$ injections do not only enhance the appearance but help to prevent the age-related changes associated with atrophy and contribute to healing of the skin.

\section{CONCLUSIONS}

According to our study, the course of intradermal injections of Collost $7 \%$ improves the aesthetic appearance of facial skin, reliably normalizes its color, reduces visibility of wrinkles. Moreover, the positive clinical dynamics occur against the background of improving biomechanical properties of the skin (better elasticity) and structural changes identified by US scanning, which indirectly signal of the dermis
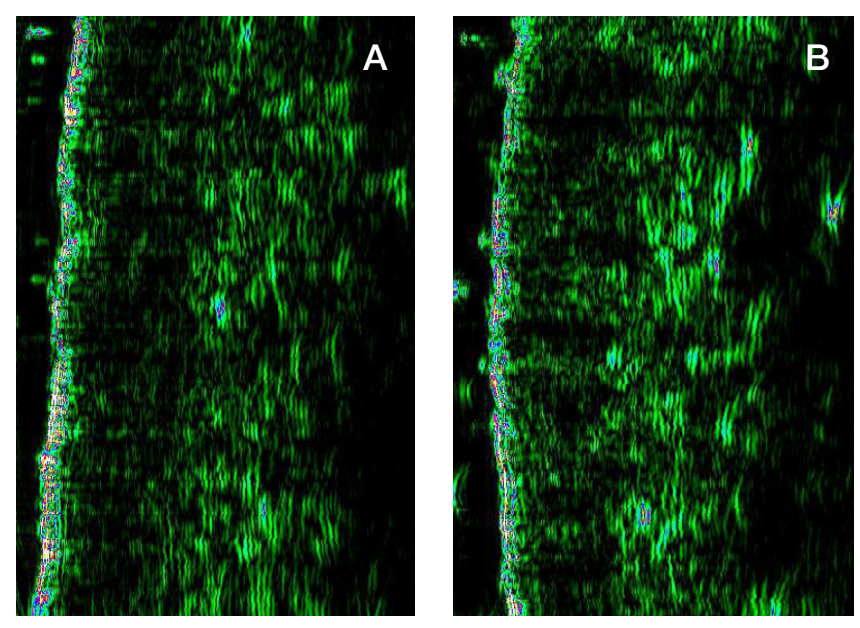

Fig. 3. US scans of forehead skin: screening (A), post-course (B)

collagen framework remodeling process. Thus, Collost $7 \%$ intradermal injections can be considered an effective and safe method of aesthetic correction. Perhaps, the results of this study will contribute to the development of etiologically and pathogenetically substantiated protocols of combined correction of age-related skin changes that would include administration of $\mathrm{HA}$, polylactic acids and high-energy methods.

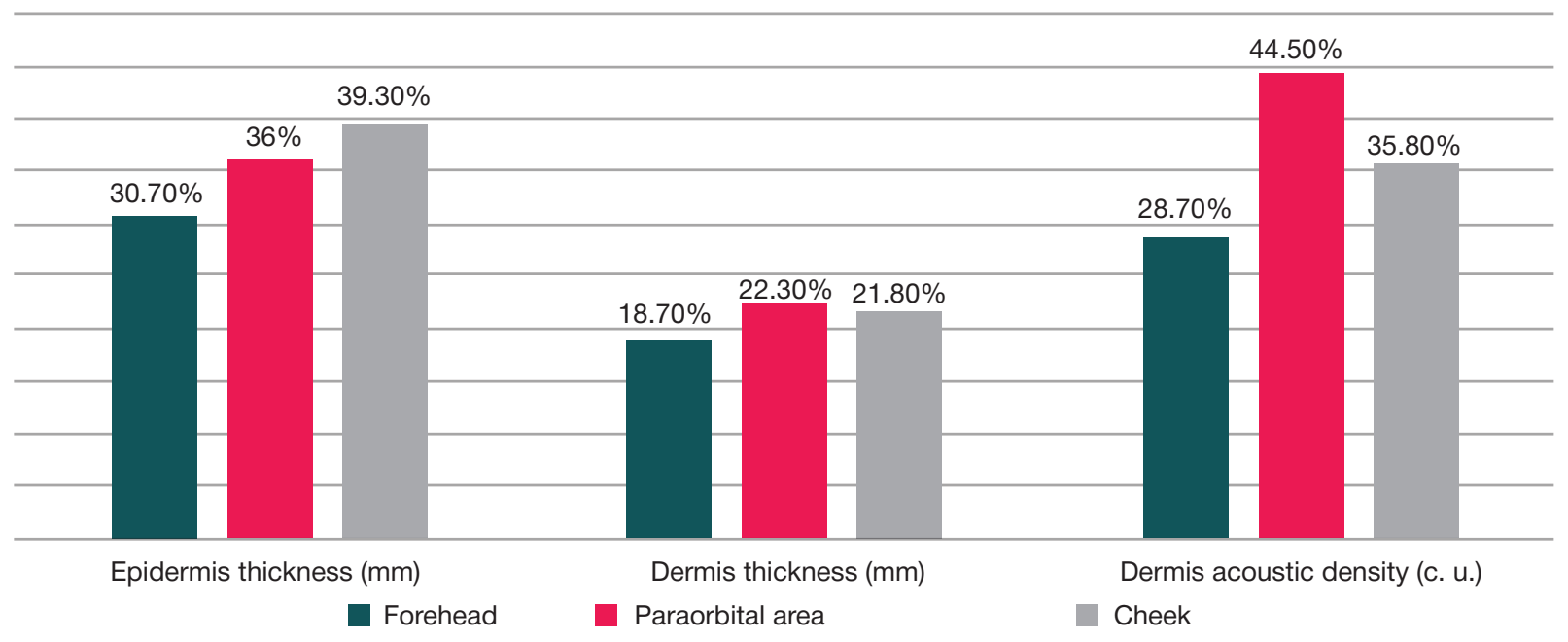

Fig. 2. Dynamics of alteration of skin structure indicators, US scans (post-course median against screening data)

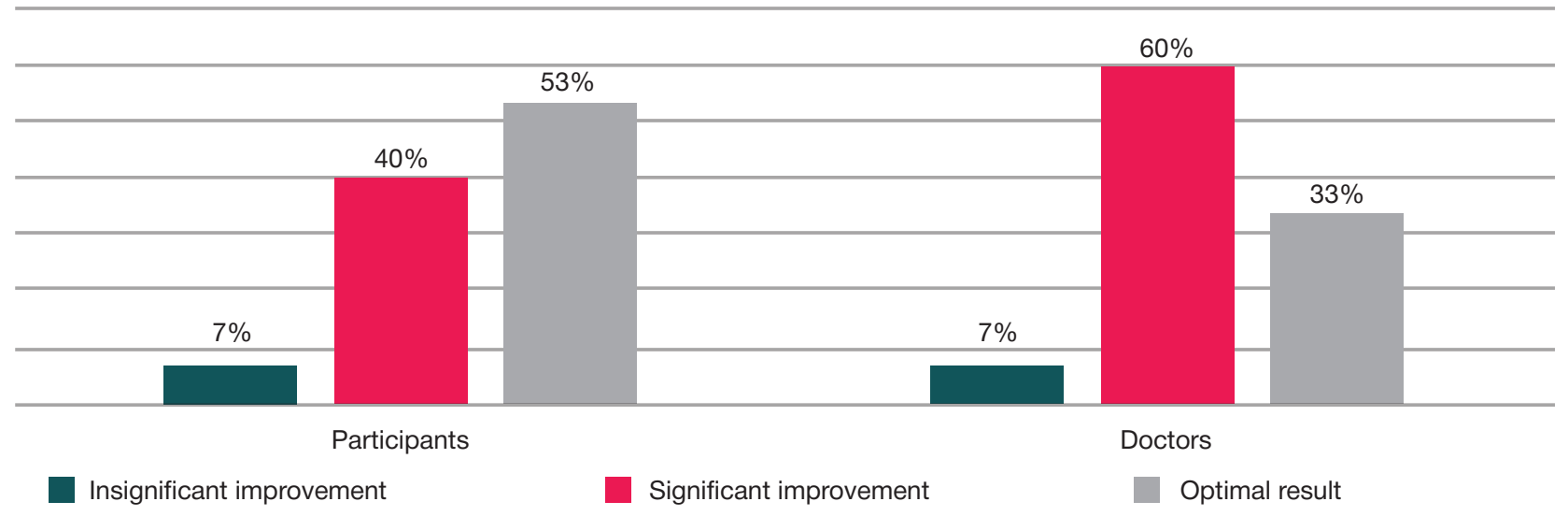

Fig. 4. Injection course efficacy assessment, GAIS, applied by participants and medical researchers 
1. Rittié L, Fisher GJ. Natural and sun-induced aging of human skin. Cold Spring Harb Perspect Med. 2015; 5 (1): a015370.

2. Gunn DA, Rexbye H, Griffiths CE, Murray PG, Fereday A, Catt SD, et al. Why Some Women Look Young for Their Age. Tregenza T, ed. PLoS ONE. 2009; 4 (12): e8021.

3. Nkengne A, Bertin C, Stamatas GN, Giron A, Rossi A, Issachar N, et al. Influence of facial skin attributes on the perceived age of Caucasian women. J Eur Acad Dermatol Venereol. 2008: 22 (8): 982-91.

4. Hussain SH, Limthongkul B, Humphreys TR. The biomechanical properties of the skin. Dermatol Surg. 2013; 39 (2): 193-203.

5. Aziz J, Shezali H, Radzi Z, Yahya NA, Abu Kassim NH, Czernuszka J, et al. Molecular Mechanisms of Stress-Responsive Changes in Collagen and Elastin Networks in Skin. Skin Pharmacol Physiol. 2016; 29 (4): 190-203.

6. Czekalla C, Schönborn KH, Döge N, Jung S, Darvin ME, Lademann J, et al. Impact of Body Site, Age, and Gender on the Collagen/Elastin Index by Noninvasive in vivo Vertical Two-Photon Microscopy. Skin Pharmacol Physiol. 2017; 30 (5): 260-7.

7. Baroni Edo R, Biondo-Simões Mde L, Auersvald A, Auersvald LA, Montemor Netto MR, Ortolan MC, et al. Influence of aging on the quality of the skin of white women: the role of collagen. Acta Cir Bras. 2012; 27 (10): 736-40.

8. Kapuler O, Selskaja B, Galeeva A, Kamilov F. Metabolizm kollagenovyh volokon na fone vozrastnyh izmenenij. Vrach. 2015; (8): 64-9.

9. Quan T, Fisher GJ. Role of Age-Associated Alterations of the Dermal Extracellular Matrix Microenvironment in Human Skin Aging: A Mini-Review. Gerontology. 2015; 61 (5): 427-34.

10. Calleja-Agius J, Brincat M, Borg M. Skin connective tissue and ageing. Best Pract Res Clin Obstet Gynaecol. 2013; 27 (5): 727-40.

11. Danby FW. Nutrition and aging skin: sugar and glycation. Clin Dermatol. 2010; 28 (4): 409-11.

12. Ahmed T, Nash A, Clark KE, Ghibaudo M, de Leeuw NH, Potter A, et al. Combining nano-physical and computational investigations to understand the nature of "aging" in dermal collagen. Int $\mathrm{J}$ Nanomedicine. 2017; (12): 3303-14.

13. Moragas A, Garcia-Bonafé $M$, Sans $M$, Torán $N$, Huguet $P$, Martin-Plata C. Image analysis of dermal collagen changes during skin aging. Analyt Quant Cytol Histol. 1998; (20): 493-9.

14. El-Domyati M, Attia S, Saleh F, Brown D, Birk DE, Gasparro F, et al. Intrinsic aging VS photoaging: a comparative histopathological, immunohistochemical and ultrastructural study of skin. Exp Dermatol. 2002; (11): 398-405.

15. Yaar M, Eller MS, Gilchrest BA. Fifty years of skin aging. J Invest Dermatol. 2002; (7): 51-8.

16. Cheng W, Yan-hua R, Fang-gang N, Guo-an Z. The content and ratio of type I and III collagen in skin differ with age and injury. African J Biotechnol. 2011; 10 (13): 2524-9.

17. Fisher GJ, Varani J, Voorhees JJ. Looking older: fibroblast collapse and therapeutic implications. Arch Dermatol. 2008; 144 (5): 666-72.

18. Cole MA, Quan T, Voorhees JJ, Fisher GJ. Extracellular matrix regulation of fibroblast function: redefining our perspective on skin aging. J Cell Commun Signal. 2018; 12 (1): 35-43.

19. Varani J, Spearman D, Perone P, Fligiel SE, Datta SC, Wang ZQ, et al. Inhibition of type I procollagen synthesis by damaged collagen in photoaged skin and by collagenase-degraded collagen in vitro. Am J Pathol. 2001; 158 (3): 931-42.

20. Sawamura S, Jinnin M, Kajihara I, Makino K, Aoi J, Ichihara A, et al. Do scleroderma patients look young? Evaluation by using facial imaging system. Drug Discov Ther. 2017; 11 (6): 342-5.

21. Kamilov FH, Selskaja BN, Danilova OV, Kapuler OM. Metabolizm kollagena v kozhe jeksperimental'nyh zhivotnyh pri intradermal'noj in'ekcii nemodificirovannogo bych'ego kollagena tipa I. Vestnik Udmurdskogo universiteta. 2017; 27 (3): 356-61.
22. Kruglikov I. Neocollagenesis in Non-Invasive Aesthetic Treatments. J Cosmet Dermatol Sci Appl. 2013; 3 (1A): 1-5.

23. Shao Y, He T, Fisher GJ, Voorhees JJ, Quan T. Molecular basis of retinol anti-ageing properties in naturally aged human skin in vivo. Int J Cosmet Sci. 2017; 39 (1): 56-65.

24. Wang F, Garza LA, Kang S, Varani J, Orringer JS, Fisher GJ, et al. In vivo stimulation of de novo collagen production caused by crosslinked hyaluronic acid dermal filler injections in photodamaged human skin. Arch Dermatol. 2007; 143 (2): 155-63.

25. Yutskovskaya Y, Kogan E, Leshunov E. A randomized, splitface, histomorphologic study comparing a volumetric calcium hydroxylapatite and a hyaluronic acid-based dermal filler. J Drugs Dermatol. 2014; 13 (9): 1047-52.

26. Stein P, Vitavska O, Kind P, Hoppe W, Wieczorek H, Schürer NY. The biological basis for poly-L-lactic acid-induced augmentation. J Dermatol Sci. 2015; 78 (1): 26-33.

27. Rao KP. Recent developments of collagen-based materials for medical applications and drug delivery systems. J Biomater Sci Polymer Ed. 1995; 7 (7): 623-45.

28. Katayama K, Armendariz-Borunda J, Raghow R, Kang AH, Seyer JM A pentapeptide from type I procollagen promotes extracellular matrix production. J Biol Chem. 1993; 268 (14): 9941-4.

29. Maquart FX, Pasco S, Ramont L, Hornebeck W, Monboisse JC. An introduction to matrikines: extracellular matrix-derived peptides which regulate cell activity. Implication in tumor invasion. Crit Rev Oncol Hematol. 2004; 49 (3): 199-202.

30. Abojanc RK, Istranov LP, Istranova EV, Rudenko TG. Plasticheskie materialy napravlennogo dejstvija na osnove kollagena. Jelektronnyj sbornik nauchnyh trudov "Zdorov'e i obrazovanie v XXI veke". 2011; (4): 184

31. Kubanova AA, Smoljannikova VA, Sluzhaeva NG. Starenie kozhi i vozmozhnosti korrekcii preparatom kollagena. Vestnik dermatologii i venerologii. 2007; (5): 70-3.

32. Kapuler OM, Kuramshina ER. Prikladnye aspekty kollagenoterapil $\checkmark$ jesteticheskoj medicine. Jeksperimental'naja i klinicheskaja dermatokosmetologija. 2013; (5): 40-3.

33. Gejnic AV, Kiani A, Okushko SS. Novye vozmozhnosti primenenija glubokoj i poverhnostnoj frakcionnoj abljacii $\vee$ anti-age terapii. Plasticheskaja hirurgija i kosmetologija. 2013; (4): 625-32.

34. Alexiades-Armenakas M, Newman J, Willey A, Kilmer S, Goldberg D, Garden J, et al. Prospective multicenter clinical trial of a minimally invasive temperature-controlled bipolar fractional radiofrequency system for rhytid and laxity treatment. Dermatol Surg. 2013; 39 (2): 263-73.

35. Carruthers A, Carruthers J. A validated facial grading scale: the future of facial ageing measurement tools? J Cosmet Laser Ther. 2010; 12 (5): 235-41.

36. Tsukahara K, Tamatsu Y, Sugawara Y, Shimada K. The relationship between wrinkle depth and dermal thickness in the forehead and lateral canthal region. Arch Dermatol. 2011; 147 (7): 822-8.

37. Waller JM, Maibach HI. Age and skin structure and function, a quantitative approach (I): blood flow, $\mathrm{pH}$, thickness, and ultrasound echogenicity. Skin Res Technol. 2005; (11): 221-35.

38. Jasaitiene D, Valiukeviciene S, Linkeviciute G, et al. Principles of high-frequency ultrasonography for investigation of skin pathology. J Eur Acad Dermatol Venereol. 2011; (25): 375-82.

39. Kozarova A, Kozar M, Minarikova E, Pappova T. Identification of the age related skin changes using high-frequency ultrasound. Acta Medica Martiniana. 2017; 17 (1): 15-20.

40. Lacarrubba F, Tedeschi A, Nardone B, Micali G. Mesotherapy for skin rejuvenation: assessment of the subepidermal lowechogenic band by ultrasound evaluation with cross-sectional B-mode scanning. Dermatol Ther. 2008; 21 (Suppl 3): 1-5.

\section{Литература}

1. Rittié L, Fisher GJ. Natural and sun-induced aging of human skin. Cold Spring Harb Perspect Med. 2015; 5 (1): a015370.
2. Gunn DA, Rexbye H, Griffiths CE, Murray PG, Fereday A, Catt SD, et al. Why Some Women Look Young for Their Age. Tregenza T, 
ed. PLoS ONE. 2009; 4 (12): e8021.

3. Nkengne A, Bertin C, Stamatas GN, Giron A, Rossi A, Issachar N, et al. Influence of facial skin attributes on the perceived age of Caucasian women. J Eur Acad Dermatol Venereol. 2008: 22 (8): 982-91.

4. Hussain SH, Limthongkul B, Humphreys TR. The biomechanical properties of the skin. Dermatol Surg. 2013; 39 (2): 193-203.

5. Aziz J, Shezali H, Radzi Z, Yahya NA, Abu Kassim NH, Czernuszka J, et al. Molecular Mechanisms of Stress Responsive Changes in Collagen and Elastin Networks in Skin. Skin Pharmacol Physiol. 2016; 29 (4): 190-203.

6. Czekalla $\mathrm{C}$, Schönborn $\mathrm{KH}$, Döge $\mathrm{N}$, Jung $\mathrm{S}$, Darvin $\mathrm{ME}$ Lademann J, et al. Impact of Body Site, Age, and Gender on the Collagen/Elastin Index by Noninvasive in vivo Vertical Two-Photon Microscopy. Skin Pharmacol Physiol. 2017; 30 (5): 260-7.

7. Baroni Edo R, Biondo-Simões Mde L, Auersvald A, Auersvald LA, Montemor Netto MR, Ortolan MC, et al. Influence of aging on the quality of the skin of white women: the role of collagen. Acta Cir Bras. 2012; 27 (10): 736-40.

8. Капулер О., Сельская Б., Галеева А., Камилов Ф. Метаболизм коллагеновых волокон на фоне возрастных изменений. Врач. 2015; (8): 64-9.

9. Quan T, Fisher GJ. Role of Age-Associated Alterations of the Dermal Extracellular Matrix Microenvironment in Human Skin Aging: A Mini-Review. Gerontology. 2015; 61 (5): 427-34.

10. Calleja-Agius J, Brincat M, Borg M. Skin connective tissue and ageing. Best Pract Res Clin Obstet Gynaecol. 2013; 27 (5): 727-40.

11. Danby FW. Nutrition and aging skin: sugar and glycation. Clin Dermatol. 2010; 28 (4): 409-11.

12. Ahmed T, Nash A, Clark KE, Ghibaudo M, de Leeuw NH, Potter A et al. Combining nano-physical and computational investigations to understand the nature of "aging" in dermal collagen. Int $J$ Nanomedicine. 2017; (12): 3303-14.

13. Moragas A, Garcia-Bonafé M, Sans $M$, Torán N, Huguet $P$, Martin-Plata C. Image analysis of dermal collagen changes during skin aging. Analyt Quant Cytol Histol. 1998; (20): 493-9.

14. El-Domyati M, Attia S, Saleh F, Brown D, Birk DE, Gasparro F, et al. Intrinsic aging VS photoaging: a comparative histopathological, immunohistochemical and ultrastructural study of skin. Exp Dermatol. 2002; (11): 398-405.

15. Yaar M, Eller MS, Gilchrest BA. Fifty years of skin aging. J Invest Dermatol. 2002; (7): 51-8.

16. Cheng W, Yan-hua R, Fang-gang N, Guo-an Z. The content and ratio of type I and III collagen in skin differ with age and injury. African J Biotechnol. 2011; 10 (13): 2524-9.

17. Fisher GJ, Varani J, Voorhees JJ. Looking older: fibroblast collapse and therapeutic implications. Arch Dermatol. 2008; 144 (5): 666-72.

18. Cole MA, Quan T, Voorhees JJ, Fisher GJ. Extracellular matrix regulation of fibroblast function: redefining our perspective on skin aging. J Cell Commun Signal. 2018; 12 (1): 35-43.

19. Varani J, Spearman D, Perone P, Fligiel SE, Datta SC, Wang ZQ, et al. Inhibition of type I procollagen synthesis by damaged collagen in photoaged skin and by collagenase-degraded collagen in vitro. Am J Pathol. 2001; 158 (3): 931-42.

20. Sawamura S, Jinnin M, Kajihara I, Makino K, Aoi J, Ichihara A, et al. Do scleroderma patients look young? Evaluation by using facial imaging system. Drug Discov Ther. 2017; 11 (6): 342-5.

21. Камилов Ф. Х., Сельская Б. Н., Данилова О. В., Капулер О. М. Метаболизм коллагена в коже экспериментальных животных при интрадермальной инъекции немодифицированного бычьего коллагена типа І. Вестник Удмуртского университета. 2017; 27 (3): 356-61.

22. Kruglikov I, Neocollagenesis in Non-Invasive Aesthetic Treatments. J Cosmet Dermatol Sci Appl. 2013; 3 (1A): 1-5.
23. Shao Y, He T, Fisher GJ, Voorhees JJ, Quan T. Molecular basis of retinol anti-ageing properties in naturally aged human skin in vivo. Int J Cosmet Sci. 2017; 39 (1): 56-65.

24. Wang F, Garza LA, Kang S, Varani J, Orringer JS, Fisher GJ, et al. In vivo stimulation of de novo collagen production caused by crosslinked hyaluronic acid dermal filler injections in photodamaged human skin. Arch Dermatol. 2007; 143 (2): 155-63.

25. Yutskovskaya $Y$, Kogan E, Leshunov E. A randomized, splitface, histomorphologic study comparing a volumetric calcium hydroxylapatite and a hyaluronic acid-based dermal filler. J Drugs Dermatol. 2014; 13 (9): 1047-52.

26. Stein P, Vitavska O, Kind P, Hoppe W, Wieczorek H, Schürer NY. The biological basis for poly-L-lactic acid-induced augmentation. J Dermatol Sci. 2015; 78 (1): 26-33.

27. Rao KP. Recent developments of collagen-based materials for medical applications and drug delivery systems. J Biomater Sci Polymer Ed. 1995; 7 (7): 623-45.

28. Katayama K, Armendariz-Borunda J, Raghow R, Kang AH, Seyer JM. A pentapeptide from type I procollagen promotes extracellular matrix production. J Biol Chem. 1993; 268 (14): 9941-4.

29. Maquart FX, Pasco S, Ramont L, Hornebeck W, Monboisse JC. An introduction to matrikines: extracellular matrix-derived peptides which regulate cell activity. Implication in tumor invasion. Crit Rev Oncol Hematol. 2004; 49 (3): 199-202.

30. Абоянц Р. К., Истранов Л. П., Истранова Е. В., Руденко Т. Г. Пластические материалы направленного действия на основе коллагена. Электронный сборник научных трудов «Здоровье и образование в XXI веке». 2011; (4): 184.

31. Кубанова А. А., Смольянникова В. А., Служаева Н. Г. Старение кожи и возможности коррекции препаратом коллагена. Вестник дерматологии и венерологии. 2007; (5): 70-3.

32. Капулер О. М., Курамшина Е. Р. Прикладные аспекты коллагенотерапии в эстетической медицине. Экспериментальная и клиническая дерматокосметология. 2013; (5): 40-3.

33. Гейниц А. В., Киани А., Окушко С. С. Новые возможности применения глубокой и поверхностной фракционной абляции в anti-age терапии. Пластическая хирургия и косметология. 2013; (4): 625-32.

34. Alexiades-Armenakas M, Newman J, Willey A, Kilmer S, Goldberg D, Garden J, et al. Prospective multicenter clinical trial of a minimally invasive temperature-controlled bipolar fractional radiofrequency system for rhytid and laxity treatment. Dermatol Surg. 2013; 39 (2): 263-73.

35. Carruthers A, Carruthers J. A validated facial grading scale: the future of facial ageing measurement tools? J Cosmet Laser Ther. 2010; 12 (5): 235-41.

36. Tsukahara K, Tamatsu Y, Sugawara Y, Shimada K. The relationship between wrinkle depth and dermal thickness in the forehead and lateral canthal region. Arch Dermatol. 2011; 147 (7): 822-8.

37. Waller JM, Maibach HI. Age and skin structure and function, a quantitative approach (I): blood flow, pH, thickness, and ultrasound echogenicity. Skin Res Technol. 2005; (11): 221-35.

38. Jasaitiene D, Valiukeviciene S, Linkeviciute $G$, et al. Principles of high-frequency ultrasonography for investigation of skin pathology. J Eur Acad Dermatol Venereol. 2011; (25): 375-82.

39. Kozarova A, Kozar M, Minarikova E, Pappova T. Identification of the age related skin changes using high-frequency ultrasound. Acta Medica Martiniana. 2017; 17 (1): 15-20.

40. Lacarrubba F, Tedeschi A, Nardone B, Micali G. Mesotherapy for skin rejuvenation: assessment of the subepidermal lowechogenic band by ultrasound evaluation with cross-sectional B-mode scanning. Dermatol Ther. 2008; 21 (Suppl 3): 1-5. 